\title{
Street Children and Money in Relation to Covid-19 Virus: Case Study for the Street Children in the Republic of South Sudan
}

\author{
Owen Ndorom \\ Studies \\ Institute of Peace, Development and Security \\ University of Juba, P.O. Box 82. Juba - South \\ Sudan \\ Jean d'Amour Banyanga \\ Åbo Academy \\ University, Faculty of Arts, Psychology and Theology, Tehtaankatu, TURKU
}

\begin{abstract}
Living as a street child is a miserable situation, and additionally, the Covid-19 pandemic that has affected millions of people and killed thousands of humans worldwide is very alarming. Money is desired by any person for its role in purchasing things essential for living. Street children beg for money and sometimes they resort to pickpocketing from people who could be carrying the Coronavirus. This study investigates the life of street children and money in relationship to Covid-19 in South Sudan. This argument is presented through an analysis of existing literature and documents on the matter. A sample of 197street children found in the streets of Juba and Yei, including eight children who were sex-workers, filled in a questionnaire. In the sample, $43.7 \%$ slept in the street. The study found that street children are at risk of contracting the Coronavirus, and because of underlying poor health conditions, they are at a higher risk of developing complications.
\end{abstract}

Keywords: Street children, Money, Covid-19 Virus and South Sudan

\section{Introduction}

The protection of children growing up in the midst of political violence and displacement has become one of the central priorities of humanitarian intervention worldwide. In conflict situations where it affects parts of the African continent, protection is generally understood as referring to those strategies that aim at reducing the risk and extent of harm to civilians, both adults and children and facilitating the re-establishment of more secure conditions. Child-centered agencies such as Save the Children have intended to protect children from violence, injury or abuse, neglect, maltreatment, and exploitation (O'Callaghan \&Pantuliano, 2007). In South Sudan, 
like in many other developing countries, there is a severe problem for the children who sleep in the streets. Consequences of sleeping in the street are in many cases fatal for the children as they easily become victims of physical violence and sexual abuse. Children also are deprived of a family cultural upbringing, which hampers their social development. Furthermore, sleeping in the streets is a human rights issue. However, Street children are the victims of lack of education systems. They are subjects of prostitution networks, abductions to become soldiers and domestic violence (UNICEF, 2006, p. 35).

The African Commission on Human and Peoples' Rights (1998) has strongly condemned all forms of violence against children. However, the problem is widespread all over the developing world and deserves attention. In a review of studies on street children in the developing world, poverty, and abuse, were related to children choosing to live in the streets (Aptekar, 1994). In addition, many children are victims of physical and emotional aggression, poverty due to parents' unemployment and this had led children to choose to sleep in the streets (Ndoromo, Österman \& Björkqvist, 2017). As a result, these children are prone to trauma and suffering from severe psychological disorders such as depression and anxiety. Therefore, they may engage in antisocial behaviors, such as drug or alcohol abuse (Banyanga, Björkqvist, \&Österman, 2018).

According to the United Nations' Convention on the Rights of the Child, children have the right to an education, to a standard of living that is good enough to meet their physical and mental needs, and they should be protected from activities that could harm their development (Le Blanc, 1995). However, many times, this convention on the rights of the child does not work in certain developing countries. Because of poverty, many children may be raped, which can lead some female street children to be ignored and marginalized by their families and communities. The children born as a result of rape are not accepted in some African communities and people argue that children born as a result of rape are considered as social burdens (Banyanga et al, 2018). Sometimes, these street children are forced laborers. Their work situations are cruelly difficult, frequently not offering the encouragement for appropriate physical and mental growth.

\section{Who are the Street Children?}

According to Ndoromo, Österman \& Björkqvist (2017), street children is a multifaceted phenomenon that is divided into three distinct categories, (a) children on the street, (b) children in the street, and (c) children of the street. The researcher argues that the first category are those children who work and play on the street, to support their household income, but go back home every evening to their families. The second are those children who exist in urban spaces and are exposed to the tortures of poverty, and mostly engage in social vices as part of a normative culture. The third group are those children who live and work on the streets, whose only sense 
of family draws from their social relations with the two other categories of street children outlined above. Historically, these children are orphans, runaway kids and abandoned children, who often at times do not know their family ties and or see them in negative light. Furthermore, the World Health Organization (2000) estimated that there are currently between 10 and 100 million street children in the world. The Researchers argued that some street children are part of entire families who live on the street. Others are born to older street girls. Some street children are 'on the street,' which means that they still see their families regularly and may even return every night to sleep in their family homes (World Health Organization, 2000).

To start to tackle the problems of keeping street children safe in this global emergency, people need to work together as a team, and governments need to highlight the urgent issues and challenges and seek to involve organizations to influence resources to urgently respond (Cohen \& Kupferschmidt, 2020). Street children need food, shelter, access to health services and protection but also information so that they can understand how to keep themselves safe. It means organizations working with street children need help with advocating for street children in times of crisis. To make sure street children are included in all emergency work that is going into Coronavirus is a huge task (Megan, Griffeth \& Ashish, 2020).

\section{Methods}

\section{Sample}

A total of 197 children, 71 girls and 126 boys, between 6 and 17 years of age, took part in the study conducted in 2020. A questionnaire was filled in by those children who could read and write; the researcher helped the others to fill it in. The children were found in Juba $(n=140)$, the capital of South Sudan, and in the smaller town of Yei $(\mathrm{n}=57)$. The girls $(\mathrm{M}=14.6$ years, $\mathrm{SD}=2.0)$ were significantly older than the boys $(\mathrm{M}=13.6$ years, $\mathrm{SD}=2.4)[(195)=2.74, \mathrm{p}=0.007]$. There was no significant age difference between children from the two cities. Nine of the girls worked in the streets; their age range was between 13 and 17 years. Tribal belonging of the children was established by the first author who is of South Sudanese origin. The largest group of children belonged to the Kakwa tribe (51.3\%), which originates from the southwestern part of South Sudan. The following tribes were also represented: Bari, Pojulu, Latuko, Baka, Mundari, Denka, Avukaya, Murle, Taposa, Nuba, Zande, Murru, Kukku, Mundu, Didinga, Peri, Acholi, Mandi, Lokoya, Balanda, and Ugandan. Tribal belonging of one child could not be established. Of the children, $97 \%$ were Christians, and $2 \%$ were Muslims.

\section{Instrument}

The questionnaire was filled in with each child individually. The following topics were covered: family background and education, daily life in the streets (e.g., work, drugs), injuries, war experiences, victimization from domestic violence, and expectations for 
the future. Injuries were rated by the researcher on a four-point scale (no injuries $=0$, small $=1$, severe $=2$, extremely severe $=3$ ). Two groups were formed based on the children's responses to the question "Where do you sleep?" (at home/in the street). Victimization from physical punishment at home was measured with three questions: how often has an adult at home (a) pulled your hair, (b) hit you with their hand, and (c) hit you with an object? Witnessing of interpersonal violence between parents was measured with two questions: how often (a) did your father hit your mother, and (b) did your mother hit your father? Responses regarding physical punishment and parental aggressive behaviors were given on a four-point scale (never $=0$, sometimes=1, often $=2$, very often $=3$ ). Questions concerning shortage of food at home, parents' alcohol problems, and sexual abuse were yes/no answers. Life stories of six randomly chosen children, expectations for the future, and drawings made by the children are presented. The field work was carried out during the period of June to October 2020. Prior to the study, cooperation had been established with Juba National University. Since research permissions were necessary in order to deal with the security interventions that were expected to take place during the data collection, local authorities in the towns Juba and Yei provided a written consent for the investigation. The researcher visited places such as Juba market, Konykonyo market, Gumbo market, Gudele market, and Jebel market where street children were expected to be found. First, he observed the children at length, familiarizing himself with their habits. Children in the street commonly form small groups with a leader. The researcher would then establish a friendly contact with the leader and ask if he would like to fill in a questionnaire. After that, other group members turned up encouraged by the leader. The data was collected sitting in the street, in marketplaces, bus stations, or sleeping places of the children in a way that the conversation could not be interrupted and overheard by others.

\section{Ethical considerations}

The study adheres to the principles concerning human research ethics of the Declaration of Helsinki (World Medical Association, 2013), as well as to the guidelines for responsible conduct of research issued by the Finnish Advisory Board on Research Integrity (2012).

\section{Results}

Many street children have no access to clean water, health care and shelter on the streets and therefore, they are at risk of contracting the virus, and because of underlying poor health conditions, they are at a higher risk of developing complications. Street children face discrimination and cruelty from communities who fear the Covid-19 virus, in which they could be those who are supposed to protect the street children, especially, the police and other authorities. Although, the name Covid19 has nothing to do with China, it originated in China and spread all over the world. Though there are countries with few reported Coronavirus cases, all state 
governments, with the help of international organizations and national and community-based organizations, should work together for prevention of this deadly disease.

However, for the safety of the South Sudanese, the government has issued an order closing borders with the neighboring countries of Uganda, Kenya, Ethiopia, Sudan, Central African Republic and the Democratic Republic of Congo. At the same, time all schools, churches, universities and Juba International airport all are closed. An order also was issued prohibiting any social gathering. However, today COVID-19 has become a pandemic disease killing people in their thousands. As a result, many countries introduced and have taken serious messes for controlling this deadly disease. However, one of the most important problems that has been neglected to be addressed is the issue of Street children in relationship to money and Coronavirus. Street children in many ways are unclean humans, and if it is not acknowledged that they may be easily affected with Coronavirus, this can lead to penetration of the Coronavirus into various areas in the Republic of South Sudan. Therefore, parentchild relationships are a central factor of social life and an individual's well-being. A poor quality of parent-child relationships is associated with psychological distress, poor physical and mental health, learning disabilities and anxiety disorders, and aggressive behavior (Banyanga, Björkqvist, \&Österman, 2017).

\section{Prevention of Coronavirus}

The first cases of novel coronavirus SARS-CoV-2 infection were reported in December 2019 in Wuhan, China (World Health Organization, 2020). Coronavirus disease 2019 (COVID-19) was declared a global pandemic by the World Health Organization on 11 March 2020, and as of 17 September 2020, there have been over 3.068 million confirmed cases and more than 954,000 deaths globally. In South Sudan, there have been 8677 confirmed cases and 102 deaths (Worldometer, 2021). Many countries have suddenly implemented strict measures to slow the spread of the disease, which the World Health Organization officially declared a pandemic on 13 March 2020. Thousands of events have been canceled, schools, restaurants, bars, and clubs have been closed and transit systems are at a standstill. The government of the Republic of South Sudan, with the help of the international, national and the community-based organization should work together for prevention of this deadly pandemic disease (Shen et al., 2020).

A common feature in many urban areas in South Sudan is young children, who are scrambling to maintain a presence in the urban area, and many of these children of school age have been abandoned by their families or in some cases the children have abandoned their families due to poverty (Ndoromo et al, 2017). However, irrespective of who abandoned these children, they definitely do not deserve thlife circumstances of destitution, squalor, disease, abuse and societal neglect (Kudrati, Plummer, Dafaalla, 2008). 


\section{Poverty, income inequality \& food security}

Over half of the population of South Sudan (51\%) live below the poverty line, defined by the Southern Sudan Commission for Census Statistics (Karmakar \& Sarkar, 2014), and the majority of rural households are headed by women, which leads some children to go and beg in the streets. Poverty and family income in South Sudan is directly correlated with the education level of the head of household. 55\% of households whose head has received no schooling live under the poverty line, compared to $11 \%$ of households headed by those with post-secondary education (Ndoromo et al, 2018).

Food insecurity and malnutrition are widespread in South Sudan. Children under the age of five are moderately or severely underweight and 34\% suffer from moderate or severe stunted growth. Localized conflict and insecurity continue to exacerbate issues of food insecurity in many regions of South Sudan (Lokosang, Ramroop \& Zewotir, 2014).

In addition, insecurity and fear of attacks severely restrict people's mobility, preventing them from accessing food markets, farms, health centers is a severe problem. Their primary objective is to understand the phenomenon of street children, to be a better advocate, one who can articulate the needs and concerns of these children with respect to the formulation of policies that will truly be beneficial to the afflicted children. A common feature among street children in Juba, the capital of South Sudan, is that there is no reliable data on the second generation of street children that is children who are the offspring of street children (Ndoromo et al, 2018).

The immediate concern about this population of street children involves the health of the babies and their mothers, and the potential disease that many of these mothers and children are exposed to. Street children, from their origins in a rural area to their destination on the streets of the capital city, their coping capabilities, and the dynamics of poverty and failure of the family system affect the whole of their life (Ayaya \& Esamai, 2001).

\section{The role of the government and non-governmental organizations}

Closure of schools and restriction on residential services has forced even more children onto the streets at greater risk of harm. The governmental authorities and non-governmental organizations that are working with street children, are in-need of practical support, they need help to speak up for the street children, who are being excluded from initiatives to reduce the spread of the Coronavirus through screening, hand washing facilities and a safe environment for self-isolation (Megan, Valerie \& Ashish, 2020). As competition for health services increases, street children will suffer even more.

\section{Discussion}


The aim of this study is to ascertain the relationship between money, street children, Coronavirus and the general public. Street children are at risk of contracting the virus, and because of underlying poor health conditions, they are at a higher risk of developing complications. Generally, protection of Civilians from acute harm is a humanitarian concern, and an issue of risk concerning child safety requires flexibility. Therefore, to understand the relationship between money, street children and the rest of public is very delicate. The approaches for protection of street children are very important and serious care must be taken, the duty of specialized actors should be encouraged and supported by both the international and national authorities. In many situations, street children are directly targeted, and laws are deliberately broken by all parties. For instance, in South Sudan the state authorities who are supposed to protect street children are in fact the main perpetrators of violence against them.

\section{References}

[1] African Commission on Human and Peoples' Rights (1998). Prevention and eradication of violence against women and children: Addendum to the SADC declaration on gender and development. Retrieved from: https://www.achpr.org/legalinstruments/detail?id=16

[2] Aptekar, L. (1994) Street children in the developing world: a review of their condition. Cross-Cultural Res 28, 195-224.

[3] Ayaya, S. 0. \& Esamai, F.O. (2001). Health problems of street children in Eldoret, Kenya. East African medical journal 78, 624-630.

[4] Banyanga J.A , Björkqvist, K. \& Österman, K. (2017). The Trauma of Women Who Were Raped and Children Who Were Born as a Result of Rape during the Rwandan Genocide: Cases from the Rwandan Diaspora. Pyrex Journal of African Studies and Development, 3: 31-39

[5] Banyanga, J.A, Björkqvist, K., Österman, K. (2017). The Trauma of Women Who Were Raped and Children Who Were Born as a Result of Rape during the Rwandan Genocide: Cases from the Rwandan Diaspora. Pyrex Journal of African Studies and Development, 3, 31-39.

[6] Cohen, J. \& Kupferschmidt, K. (2020). Countries test tactics in war against Covid-19. Science 367, 1287-1288.

[7] Finnish Advisory Board on Research Integrity (2012). Guidelines for responsible conduct of research and procedures for handling allegations of misconduct in Finland. Retrieved from: http://www.tenk.fi/sites/tenk.fi/files/HTK ohje 2012.pdf

[8] Karmakar, S., \& Sarkar, D. (2014). Income inequality, poverty and food security in West Bengal, India. Journal of Social Science Studies, 1, 31-43.

[9] Kudrati, M., Plummer, M. L., Dafaalla N. Y. (2008). Children of the Sug: a study of the daily lives of street children in Khartoum, Sudan with intervention recommendations. Child abuse \& neglect 32, 439-448. 
[10] Lokosang, L.B., Ramroop, S., Zewotir, T. (2014). Indexing household resilience to food insecurity shock: the case of South Sudan. Agrekon, 53, 137-159.

[11] Megan, L. R., Griffet, V., Ashish, K. J. (2020). Critical supply shortages and the need for ventilators and personal protective equipment during the Covid-19 pandemic. New England journal of medicine. DOI: 10.1056/NEJMp2006141

[12] Ndoromo, O., Österman, K. \& Björkqvist, K. (2017). Domestic violence as a risk factor for children ending up sleeping in the streets of post-war South Sudan. Journal of child \& Adolescent Behavior. DOI: 10.4172/23754494.1000335

[13] Ndoromo, O., Österman, K. \& Björkqvist, K. (2018). Sex differences in perpetration of low intensity intimate partner aggression in South Sudan. European journal of Interdisciplinary studies 4, 93-101.

[14] Nicola, M., Alsafi, Z., Sohrabi, C., Kerwan, A., Al-Jabir, A., Iosifidis, C., Agha, M., \& Aghaf, R. (2020). The socio-economic implications of the coronavirus pandemic (COVID-19): A review. Elsevier Public Health Emergency Collection, 78, 185, 2020

[15] O'Callaghan, S., \& Pantuliano, S. (2007). Protective Action: Incorporating Civilian Protection into Humanitarian Response. London, UK

[16] Sarah. A. Moore, Guy Faulkner, Ryan E, Rhodes, et al, (2020). Impact of the Covid-19 virus outbreak on movement and play behaviours of Canadian Children and Youth: a nation survey. International journal of behavioral Nutrition and Physical Activity 17, 1-11.

[17] Shen, K., Yang, Y., Wang, T., Zhao, D., Jiang, Y., Jin, R., Zheng, Y., Xu, B, Xie, Z., Lin, L., Shang, Y, Lu, X., Shu, S., Bai, Y., Deng, J., Lu, M., Ye, L., Wang, X., Wang, Y., Gao, L. (2020). Diagnosis, treatment, and prevention of 2019 novel Coronavirus infection in Children: experts' consensus statement. World journal of pediatrics, 16, 223-231.

[18] UNICEF (2006). The state of the World's children: Excluded and invisible. New York, United Nations.

[19] World Health Organization (2000). Working with Street Children. Retrieved from: jsessionid=8C6F17C5079F40E6962E4F6C9A955A21 WHO_MSD_MDP_00.14.pdf;

[20] World Medical Association Declaration of Helsinki (2013). Ethical principles for medical research involving human subjects. JAMA, 310, 2191-2194.

[21] Worldometer. (2021). Covid-19 Corona virus pandemic. Retrieved from: https://www.worldometers.info/coronavirus/country/south-sudan/ 